\title{
Application of a customized pathway-focused microarray for gene expression profiling of cellular homeostasis upon exposure to nicotine in $\mathrm{PC} 12$ cells ${ }^{\text {ts }}$
}

\author{
Özlen Konu ${ }^{1}$, Xiaoyuan Xu, Jennie Z. Ma, Justin Kane, Ju Wang, Shirley J. Shi, Ming D. Li* \\ Program in Genomics and Bioinformatics on Drug Addiction, Department of Psychiatry, The University of Texas Health Science Center at San Antonio, \\ 7703 Floyd Curl Drive, Mail Code 7792, San Antonio, TX 78229-3900, USA
}

Accepted 14 November 2003

\begin{abstract}
Maintenance of cellular homeostasis is integral to appropriate regulation of cellular signaling and cell growth and division. In this study, we report the development and quality assessment of a pathway-focused microarray comprising genes involved in cellular homeostasis. Since nicotine is known to have highly modulatory effects on the intracellular calcium homeostasis, we therefore tested the applicability of the homeostatic pathway-focused microarray on the gene expression in PC-12 cells treated with $1 \mathrm{mM}$ nicotine for $48 \mathrm{~h}$ relative to the untreated control cells. We first provided a detailed description of the focused array with respect to its gene and pathway content and then assessed the array quality using a robust regression procedure that allows for the exclusion of unreliable measurements while decreasing the number of false positives. As a result, the mean correlation coefficient between duplicate measurements of the arrays used in this study (control vs. nicotine treatment, three samples each) has increased from $0.974 \pm 0.017$ to $0.995 \pm 0.002$. Furthermore, we found that nicotine affected various structural and signaling components of the AKT/PKB signaling pathway and protein synthesis and degradation processes in PC-12 cells. Since modulation of intracellular calcium concentrations $\left(\left[\mathrm{Ca}^{2+}\right]_{\mathrm{i}}\right)$ and phosphatidylinositol signaling are important in various biological processes such as neurotransmitter release and tissue pathogenesis including tumor formation, we expect that the homeostatic pathway-focused microarray potentially can be used for the identification of unique gene expression profiles in comparative studies of drugs of abuse and diverse environmental stimuli, such as starvation and oxidative stress.
\end{abstract}

(C) 2003 Elsevier B.V. All rights reserved.

Theme: Neurotransmitters, modulators, transporters, and receptors

Topic: Signal transduction: gene expression

Keywords: Nicotine; Focused microarray; Cellular homeostasis; PC-12 cells; Gene networks; AKT/PKB signaling

\section{Introduction}

High-density microarrays are highly informative for identifying candidate genes involved in a disease [5,7] and providing a gene expression profile upon exposure to a specific drug treatment [29]. Alternatively, a focused microarray provides a more feasible approach due to its cost-effectiveness and supervised nature, making the data

\footnotetext{
¿ Özlen Konu and Xiaoyuan Xu contributed equally to this work.

* Corresponding author. Tel.: +1-210-567-0830; fax: +1-210-5670853.

E-mail address: lim2@uthscsa.edu (M.D. Li)

${ }^{1}$ Present address: Department of Molecular Biology and Genetics, Bilkent University, Ankara, Turkey.
}

acquisition and analysis less intimidating. Several focused microarrays have been reported in the literature, most of which were generated on the basis of previously reported studies and high-throughput gene expression profiles focusing on a particular subject of interest. For example, based on the analysis of metabolic pathways and previous linkage and association studies involving diabetes type II subtype, Walder et al. [38] developed a customized microarray containing 210 genes that is applicable for studying gene expression in insulin resistance. With this array, they reported that $7 \%$ of the genes printed on the array were modulated by insulin treatment. Based on information in the literature on early response genes from various experimental systems, Wurmbach et al. [42] developed a focused array containing 956 genes and used it to study the response of 
various transcriptional factors and cytoskeletal proteins to gonadotropin-releasing hormone receptor activation. Using a similar approach, Sawiris et al. [30] performed gene expression profiling of ovarian tumors based on OVACHIP, a specialized microarray containing 516 cDNAs chosen from serial analysis of gene expression (SAGE) and cDNA array studies on ovarian cancer. Their array allowed for identification of a unique expression profile for ovarian tumors, separating them from tumors of the colon.

In the present study, we report development of a customized microarray focusing mainly on cellular homeostatic pathways. The homeostatic pathway-focused microarray comprises a selected set of 704 cDNAs, most of which have been sequence verified and fully annotated in our laboratory. This focused array contains a comprehensive gene set involved in maintaining the homeostasis within a cell, such that their modulation by environmental stimuli such as ligand activation, starvation, and oxidative stress are likely to produce unique expression signatures. Herein, we first present an overview of the homeostatic pathway-focused array with respect to its gene and pathway content. Then, we assess the quality of microarray data based on experiments performed on undifferentiated PC-12 cells with and without exposure to nicotine, a known cholinergic agonist with significant effects on intracellular calcium concentration, $\left[\mathrm{Ca}^{2+}\right]_{\mathrm{i}}$. $\mathrm{PC}-12$ cells, cloned from a rat pheochromocytoma, are neoplastic chromafin cells that secrete various catecholamines, such as dopamine and norepinephrine, and are known to respond to cholinergic stimuli. For example, nicotine induces a rapid increase in $\left[\mathrm{Ca}^{2+}\right]_{\mathrm{i}}$, a transient effect mediated by voltage-gated calcium channels (VGCC), which then is followed by a more steady rise in $\left[\mathrm{Ca}^{2+}\right]_{i}$ via activation of store-operated calcium channels and accumulation of inositol $(1,4,5)$-trisphosphate (IP3) [9,21]. In this study, PC-12 cells were used as a model for testing the widespread effects of nicotine on expression of genes that are involved in regulating different processes of cellular homeostasis, such as cell growth and division, protein modification and degradation, as well as nicotinic acetylcholine receptor (nAChR)-coupled cellular signaling. Based on the analyses of microarray data, the unique transcriptional profile of nicotine exposure on undifferentiated PC-12 cells is discussed in terms of a genetic network involving different components of AKT/ PKB signaling.

\section{Materials and methods}

\subsection{Selection of genes for pathway-focused microarray and microarray production}

Genes were selected based on information extracted from the literature, our previously published studies $[17,20]$, and signaling pathway-related websites (www.biocarta.com; http://www.genome.ad.jp/kegg) that demonstrate the con- nectivity of genes involved in calcium and phosphatidylinositol signaling and other interacting pathways. A total of 704 mouse or rat genes were obtained from the National Institute on Aging (NIA) 15K mouse gene set [32] or Research Genetics (in cases for genes of interest that were unavailable from the NIA set). Bacterial cells containing the clones of interest were grown overnight in GS-96 medium (Biol 101 Systems, CA) and followed by incubation of $10 \mu \mathrm{l}$ cell culture plus $90 \mu \mathrm{l}$ water at $95{ }^{\circ} \mathrm{C}$ for $10 \mathrm{~min}$ to release plasmid DNA from the cells. A 10- $\mu 1$ sample of supernatant containing plasmid DNA was added to a PCR cocktail mixture containing Taq DNA polymerase in a total volume of $100 \mu$ l. The reactions were initially denatured at $95{ }^{\circ} \mathrm{C}$ for $3 \mathrm{~min}$ and then subjected to 35 cycles of denaturation $\left(95^{\circ} \mathrm{C}\right.$, $30 \mathrm{~s})$, annealing $\left(55^{\circ} \mathrm{C}, 30 \mathrm{~s}\right)$, and extension $\left(72{ }^{\circ} \mathrm{C}, 2 \mathrm{~min}\right)$. PCR products were ethanol precipitated, washed, and dissolved into $20 \mu \mathrm{l}$ of TE buffer. Upon addition of $30 \mu \mathrm{l}$ of $80 \%$ dimethyl sulfoxide, PCR products (at a final concentration of approximately $0.25-0.50 \mu \mathrm{g} / \mu \mathrm{l}$; depending on clone) were printed in duplicates on CMT-GAPS-coated slides (Corning, NY) using an Affymetrix GMS 417 arrayer (Santa Clara, $\mathrm{CA}$ ) and then processed as suggested by the manufacturer. After arraying, slides were UV linked, washed in $3 \times \mathrm{SSC}$ twice and in $\mathrm{H}_{2} \mathrm{O}$ once, incubated with IBlock at $60{ }^{\circ} \mathrm{C}$ for $30 \mathrm{~min}$, followed by washing and kept in an airtight desiccator until use. Moreover, we have sequenced all cDNA clones included in the pathway-focused array using the following procedure. Briefly, plasmid DNA was prepared from the cDNA clones using Templiphil ${ }^{\mathrm{TM}}$ DNA Sequencing Template Amplification kit (Amersham Biosciences, NJ). All clones were sequenced using standard dye primer chemistry by an ABI PRISM ${ }^{\circledR} 310$ Genetic Analyzer (Applied Biosystems, CA). The resulting sequences were put through blast-searches to identify the similar sequences present in public databases and annotated using a custom-built computer program in the laboratory.

\subsection{PC-12 cell cultures and nicotine treatment}

PC-12 cells were obtained from American Type Culture Collection (Manassas, VA) and maintained in Ham's F12-K medium supplemented with $15 \%$ heat-inactivated horse serum, $2.5 \%$ fetal bovine serum, $2 \mathrm{mM}$ L-glutamine and adjusted to contain $1.5 \mathrm{~g} / 1$ sodium bicarbonate in a humidified atmosphere at $37{ }^{\circ} \mathrm{C}$ and $5 \% \mathrm{CO}_{2}$. Cells were treated at a medium density. For nicotine treatment, the nicotine solution in sterile water was added to a final concentration of $1 \mathrm{mM}$, and the cells were incubated for $48 \mathrm{~h}$ prior to RNA extraction [33]. Samples used in this study were obtained from three independent culture replicates for each experimental group (i.e., control and nicotine culture).

\subsection{RNA isolation and microarray hybridization}

Total RNA was isolated using TRIzol reagent according to the manufacturer's protocol (Life Technologies, MD). 
Before use, RNA samples were treated with RNase-free DNAse I at $37{ }^{\circ} \mathrm{C}$ for $30 \mathrm{~min}$. Total RNA quality was assessed by visualization of the ethidium bromide-stained $28 \mathrm{~S}$ and $18 \mathrm{~S}$ ribosomal RNA bands. Total RNA was amplified using the $\mathrm{T} 7$ amplification protocol reported previously [37]. cDNA probes were prepared as described previously with minor modifications [17]. Briefly, approximately $2 \mu \mathrm{g}$ of total RNA was added to a cocktail containing $2 \mu \mathrm{l}$ of $0.1 \mathrm{M}$ DTT, $1.0 \mu \mathrm{l}$ RNasin, $20 \mu \mathrm{l} 2.5 \mathrm{mM}$ dCTP, $1 \mu \mathrm{g}$ of Cy-3 labeled random nanomer (Tri-Link Technology, CA), and $2.0 \mu \mathrm{l}$ Superscript RT II. The labeling mixtures were incubated at $42{ }^{\circ} \mathrm{C}$ for $1.5 \mathrm{~h}$, then at $85{ }^{\circ} \mathrm{C}$ for $5 \mathrm{~min}$, followed by ethanol precipitation. The cDNA pellet was dissolved into $100 \mu \mathrm{l}$ of hybridization buffer containing $25 \%$ formamide, $5 \times \mathrm{SSC}$, and $0.1 \% \mathrm{SDS}$. The reconstituted cDNA probe was purified through a microcon YM-30 column and brought up to $110 \mu \mathrm{l}$ with hybridization buffer. A $1-\mu \mathrm{g}$ sample of Cot I DNA and $1 \mu \mathrm{g}$ of poly-(A) oligonucleotides were added to the probe mixture, denatured at $85{ }^{\circ} \mathrm{C}$ for $5 \mathrm{~min}$, and then added to the array with a cover slip placed over the array, followed by incubation at $42{ }^{\circ} \mathrm{C}$ overnight. Hybridized slides were washed once in $1 \times \mathrm{SSC}$, $0.1 \%$ SDS, and $1 \mathrm{mM}$ DTT for $10 \mathrm{~min}$ at $42{ }^{\circ} \mathrm{C}$ and in $0.1 \times \mathrm{SSC}, 0.2 \%$ SDS and $1 \mathrm{mM}$ DTT for $5 \mathrm{~min}$ at room temperature, then spun down to displace the liquid and scanned on a GenePix 4000B (Axon Instruments, CA) Scanner. Furthermore, each slide was hybridized separately with a Cy-5-labeled oligonucleotide probe (5'-Cy5-CCTATAGTGAGTCGTATTAGAGCTTGGCGTAATCATGGTCATAGCTGTTTCCTGTGTGAA-3') that is complementary to the cloned plasmid for assessing the uniformity of printing.

\subsection{Data acquisition, quality assessment, and data analysis}

\subsubsection{Data acquisition}

Upon scanning of hybridized slides using a GenePix 4000B scanner (Axon Instruments), we obtained the value of raw hybridization intensity for each spot from GenePix (v. 3.0) and then used the background-subtracted median intensity measurement (i.e., F532 Median-B532 column) on each spot for further data analysis. Spots with negative values due to the subtraction of background measurement were assigned an arbitrary minimum value of 1 . All measurements were logarithmically transformed at base 2, i.e., $E_{i j k m}$, where $i, j, k$, and $m$ refer to the identity of gene/EST/clone $(N=768)$, of treatment groups (control or nicotine), of individual samples $(N=3)$, and of duplicates $(N=2)$, respectively.

\subsubsection{Duplicate reliability assessment through robust regression}

Log-transformed duplicate measurements (i.e., 768 clones $\times 2=1536$ spots per slide) obtained from each slide were used for the assessment of replicate reliability. Correlation coefficients were calculated between duplicate measurements before and after filtering out the unreliable measurements, which is used to assess the effect of removing unreliable spots on the correlation coefficients. Each pair of duplicate spots was associated with a weight, $w$, calculated using the iteratively reweighted least squares algorithm (MatLab ${ }^{\mathrm{TM}}$, see robustfit function for details of the algorithm). In brief, $w$ ranges from 0 to 1 , such that an observation with a high $w$ value represents a better fit to the regression model. In this procedure, $E_{i k 1}$ was iteratively fit to $E_{i k 2}$ for each slide, separately $(N=6)$; and at each iteration, a new weight vector $\left(N_{\mathrm{w}}=768 \times 1\right)$, adjusting the contribution of each observation on the regression, was calculated as a function of residuals from the previous regression. As a result, the regression coefficient from the robust regression is less sensitive to the presence of outliers when compared with the one obtained from ordinary least squares regression. Accordingly, we assumed that a measurement with a weight of zero was unreliable and eventually was excluded from normalization procedures. For each clone printed in duplicate, an average weight across all slides under the analysis also was obtained.

\subsubsection{Data normalization}

Once unreliably measured spots were determined based on the weight assignment by robust regression, we globally normalized the log-transformed data by subtracting slidespecific median expression from the intensity of each spot for each slide. Median expression was calculated solely based on spots that were reliably measured for all slides that constituted the experiment. A normalization step, whether global or intensity dependent, is necessary in order to compare expression levels of individual slides $[6,15]$. In the present study, the global normalization method based on median centering of microarray data was adopted since expression values obtained from each slide were linearly and highly correlated with all the others.

\subsubsection{Determination of differentially expressed genes between control and nicotine-treated PC-12 cells}

In this study, we were interested in the identification of a set of genes that could uniquely define the homeostatic expression profile upon exposure to nicotine. Analysis of variance (ANOVA) was used to determine differentially expressed genes between control and nicotine-treated experimental groups. Since our studies were based on single channel for both experimental groups (to reduce dye bias), we have subtracted the mean control expression value from the normalized intensity of each gene across all slides. This allowed us to visualize individual samples on a cluster image as well as to increase the ability of the cluster algorithm to take into account the differences within and between samples. Publicly available cluster programs CLUSTER and TREEVIEW (http://rana.lbl.gov/EisenSoftware.htm) were used for hierarchical clustering of a gene set that was found to be significantly modulated after $48 \mathrm{~h}$ of nicotine treatment. 


\subsubsection{Analytical tools}

MATLAB and SAS packages (MATLAB ${ }^{\circledR}$, MA; SAS ${ }^{\circledR}$, Cary, NC) were used to develop analytical tools required for the analysis of the homeostatic pathway-focused microarrays. Two modules, namely, selectslides and analyzeslides have been written in MATLAB. The selectslides module is used to generate an experiment-specific data structure upon reading raw intensity data files obtained as GenePix 3.0 format. Experimental data structures are then fed into the analyzeslides module to perform normalization and statistical analysis for the comparison of group means, as well as to extract data for cluster analysis. Routines are also available in the SAS version to read GenePix raw data files and perform statistical tests using mixed models of ANOVA. The source codes for the programs mentioned above are available upon request.

\subsection{Confirmation of microarray by real-time RT-PCR}

Results of microarray data from a set of functionally related genes involved in AKT/PKB signaling, i.e., protein kinase $\mathrm{C} \zeta(\mathrm{PKCZ})$, mammalian target of rapamycin
(FRAP1/mTOR), and integrin-linked kinase (ILK) were confirmed by using real-time RT-PCR. Optimal RT-PCR conditions were determined by the strategy described previously [19], with minor modifications for real-time RT-PCR $[4,17]$. Briefly, total RNA concentration of each sample was measured in duplicate using a RIBOGreen ${ }^{\mathrm{TM}}$ kit (Molecular Probes, Eugene, OR). Then, $0.5 \mu \mathrm{g}$ of total RNA was reverse transcribed in a final volume of $20 \mu \mathrm{l}$ containing $4 \mu \mathrm{l}$ of $5 \times$ reverse transcriptase buffer $(0.1 \mathrm{M}$ Tris $-\mathrm{HCl}, \mathrm{pH} 8.8 ; 0.5 \mathrm{M}$ $\mathrm{KCl}, 1 \%$ Triton X-100), $5 \mathrm{mM} \mathrm{MgCl} 2,10 \mathrm{mM}$ DTT, 0.625 $\mathrm{mM}$ of each dNTP, $20 \mathrm{U}$ RNasin, $1 \mu \mathrm{l}$ of $50 \mathrm{mM}$ random hexamers and $200 \mathrm{U}$ SuperScript II RNase $\mathrm{H}^{-}$reverse transcriptase (Gibco Life Technologies, Grand Island, $\mathrm{NY}$ ). The RT mixtures were incubated at $42{ }^{\circ} \mathrm{C}$ for 1 $\mathrm{h}$ and then heated at $95{ }^{\circ} \mathrm{C}$ for $5 \mathrm{~min}$ to inactivate the reverse transcriptase. Amplification of $4 \mu \mathrm{l}$ RT mixture (equivalent to $0.1 \mu \mathrm{g}$ total RNA) was carried out using core reagents from the SYBR ${ }^{\circledR}$ Green kit (PE Biosystems, Foster City, CA) containing $5 \mu \mathrm{l} 10 \times$ SYBR $^{\circledR}$ Green PCR buffer, $4.0 \mu 125 \mathrm{mM} \mathrm{MgCl}_{2}, 1.0 \mu 112.5 \mathrm{mM}$ dNTP mixture with dUTP, $1 \mu \mathrm{l}$ of sense or antisense primers $(0.1 \mu \mathrm{g} / \mu \mathrm{l})$, and 2.5 $\mathrm{U}$ AmpliTaq DNA polymerase in a total volume of $50 \mu \mathrm{l}$.

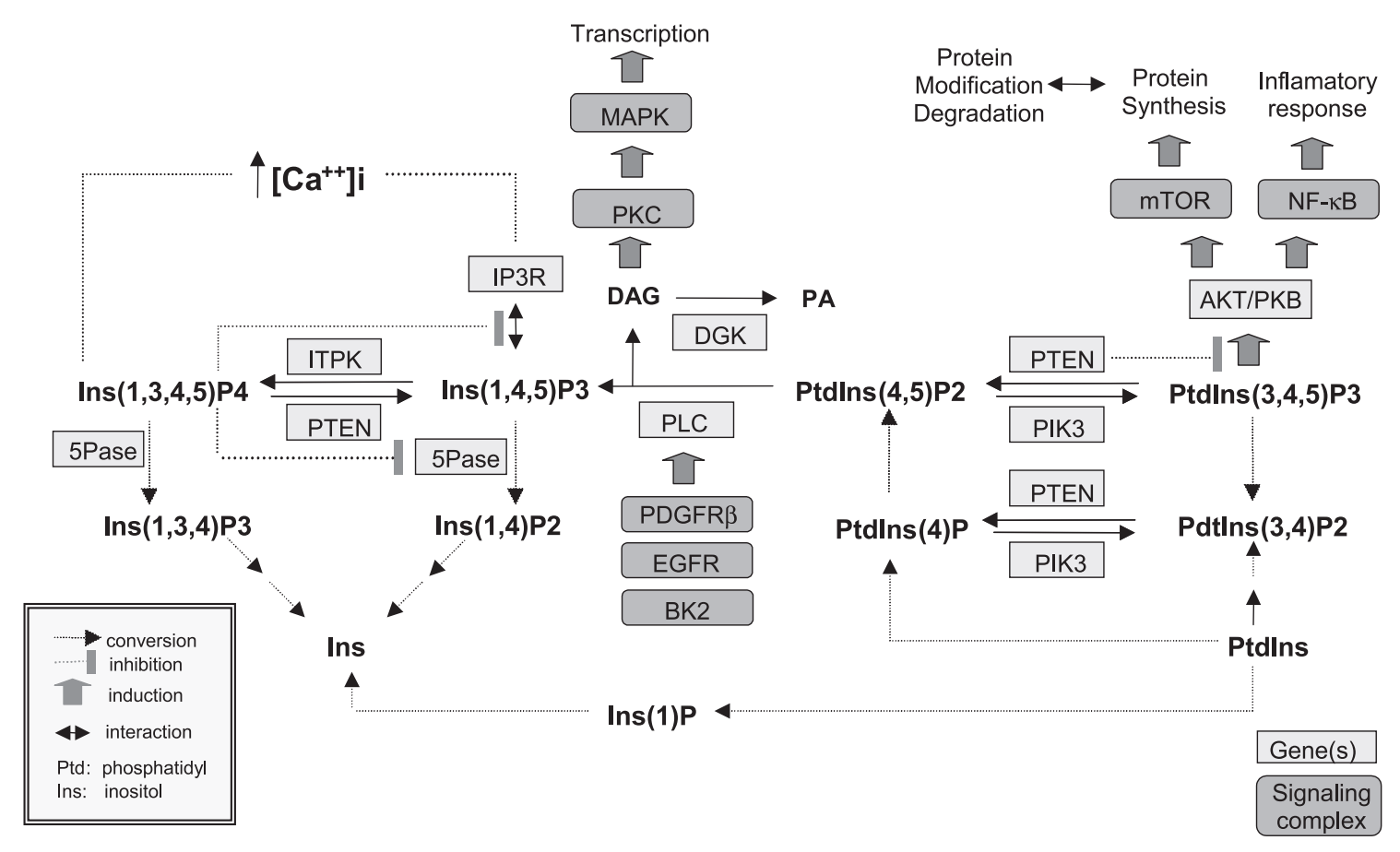

Fig. 1. A simplified overview of the homeostatic pathway-focused microarray. Conversion of PtdIns(4,5)P2 into Ins(1,4,5)P3 and DAG by PLC elevates intracellular calcium concentration $\left(\left[\mathrm{Ca}^{2+}\right]_{\mathrm{i}}\right)$ by activating IP3R on the endoplasmic reticulum. PLC activation takes place upon signaling via PDGFR $\beta$, EGFR, and G-protein-coupled receptors such as BK2. Production of DAG results in the activation of DAG-sensitive PKC isoforms leading to activation of MAPK, which in turn regulates activity of various transcriptional factors. The PLC-driven increase in $\left[\mathrm{Ca}^{2+}\right]_{\mathrm{i}}$ is further accentuated via activation of the store-operated calcium current in the presence of both Ins( $(1,3,4,5) \mathrm{P} 4$ and $\operatorname{Ins}(1,4,5) \mathrm{P} 3$. Overexpression of ITPK producing excess amounts of Ins $(1,3,4,5) \mathrm{P} 4$ may deplete Ins( $(1,4,5) \mathrm{P} 3$, thereby inhibiting the IP3R-mediated calcium influx. On the other hand, PtdIns(4,5)P2 is converted to PtdIns $(3,4,5) \mathrm{P} 3$ and activates AKT/PKB signaling that may lead to increased protein synthesis (via mTOR) and inflammatory response (via NF-KB). PTEN antagonizes the PIK3/AKT/PKB pathway, whose constitutive activation is associated with progression of a variety of cancers. Abbreviations: PIK3: phosphatidylinositol 3-kinase; PTEN: phosphate and tensin homolog; 5Pase: inositol 5-phosphatase activity; PLC: phospholipase C; DAG: 1,2-diacylglycerol; DGK: diacylglycerol kinase; PA: phosphatidic acid; ITPK: inositol(1,4,5)-trisphosphate 3-kinase; IP3R: inositol(1,4,5)P3 receptor; PKC: protein kinase C; MAPK: mitogen-activated protein kinase; AKT/PKB: $\mathrm{v}$-akt murine thymoma viral oncogene homolog; NF-kB: nuclear factor kappa B; mTOR: mammalian target of rapamycin; PDGFR $\beta$ : platelet-derived growth factor receptor beta; EGFR: epidermal growth factor receptor; BK2: bradykinin receptor type 2. 
Table 1

A general categorization of the homeostatic pathway-focused microarray, with examples given for each category

\begin{tabular}{|c|c|c|}
\hline General function & Examples & $\begin{array}{l}\text { Number } \\
\text { of genes }\end{array}$ \\
\hline Signal transduction & $\begin{array}{l}\text { cAMP, calcium, } \\
\text { phosphatidylinositol, growth } \\
\text { factors/receptors, MAPK }\end{array}$ & 244 \\
\hline $\begin{array}{l}\text { Protein modification } \\
\text { and degradation }\end{array}$ & $\begin{array}{l}\text { ubiquitin/proteasome, heat-shock } \\
\text { proteins, chaperonins }\end{array}$ & 78 \\
\hline Transcription factors & $\begin{array}{l}\text { general transcription factor IIH, } \\
\text { transcription elongation factors }\end{array}$ & 56 \\
\hline Transport & $\begin{array}{l}\text { ion channels, small molecules } \\
\text { transporters }\end{array}$ & 55 \\
\hline Protein synthesis & ribosomal protein subunits & 51 \\
\hline Cell division & $\begin{array}{l}\text { cyclins, histones, histone } \\
\text { deactylases }\end{array}$ & 47 \\
\hline $\begin{array}{l}\text { Neuronal structure } \\
\text { and transmission }\end{array}$ & $\begin{array}{l}\text { neuron-enriched proteins, } \\
\text { neurotransmitters and receptors }\end{array}$ & 38 \\
\hline Cell structure & laminins, tubulins & 23 \\
\hline Metabolism & cytochrome $P 450$ & 22 \\
\hline Other & miscellaneous functions & 24 \\
\hline Total & & 638 \\
\hline
\end{tabular}

Real-time RT-PCR reactions were initially denatured at 94 ${ }^{\circ} \mathrm{C}$ for $3 \mathrm{~min}$ and then were subjected to 40 cycles of denaturation $\left(94{ }^{\circ} \mathrm{C}, 30 \mathrm{~s}\right)$, annealing $\left(60{ }^{\circ} \mathrm{C}, 30 \mathrm{~s}\right)$, and extension $\left(72{ }^{\circ} \mathrm{C}, 45 \mathrm{~s}\right)$ using a Bio-Rad iCycler (Bio-Rad, Hercules, CA). After the last cycle, a melting curve was run to check for product purity. The expression level of each gene was determined after specifying a fluorescent level corresponding to the log-linear growth phase of the PCR reaction for each gene, and corresponding threshold cycles were determined using the analysis software available in the
Bio-Rad iCycler. Upon normalizing target gene expression of the sample to its $18 \mathrm{~S}$ rRNA expression, RT-PCR data were analyzed using the $\Delta \Delta$-CT method as previously described [41]. Moreover, ANOVA was used to test the significance of the difference in expression between control and nicotine-treated PC-12 cells for each of the three genes separately ( $N=3$ per group). The primer sequences used for PCR amplification were as follows: PKC $\zeta$ : forward: 5'CGCACATCTTCCACAGAGAC-3', reverse: 5'-ATTCTTCAGGGCATTACACG-3', predicted size: 77 bp; FRAP1: forward: 5'-CAGGTGTGCCAGGATCTCAG-3', reverse: 5'-AGTCCCTGCTGCAAACACAA-3', predicted size: 90 bp; and ILK: forward: 5'-GCAAAGCGACCCA AGTTTGA-3', reverse: 5'-TTCTGGAGTTTGGGCAA GGA-3', predicted size: 90 bp.

\section{Results}

\subsection{Gene/pathway content and sequence confirmation of the homeostatic pathway-focused microarray}

Previous studies demonstrated that genes involved in regulating calcium homeostasis lie at the center of many signal transduction events. $\left[\mathrm{Ca}^{2+}\right]_{i}$ also is in very close connection with phosphatidylinositol (PI) signaling, through which many downstream effectors, such as AKT/ $\mathrm{PKB}$, are modulated. AKT/PKB is important in various cellular processes as well as associated disease conditions such as insulin resistance [43], tumor onset and progression [25], and drug addiction and neurodegenerative diseases [16]. The homeostatic pathway-focused array containing a highly interconnected set of genes involved in cellular
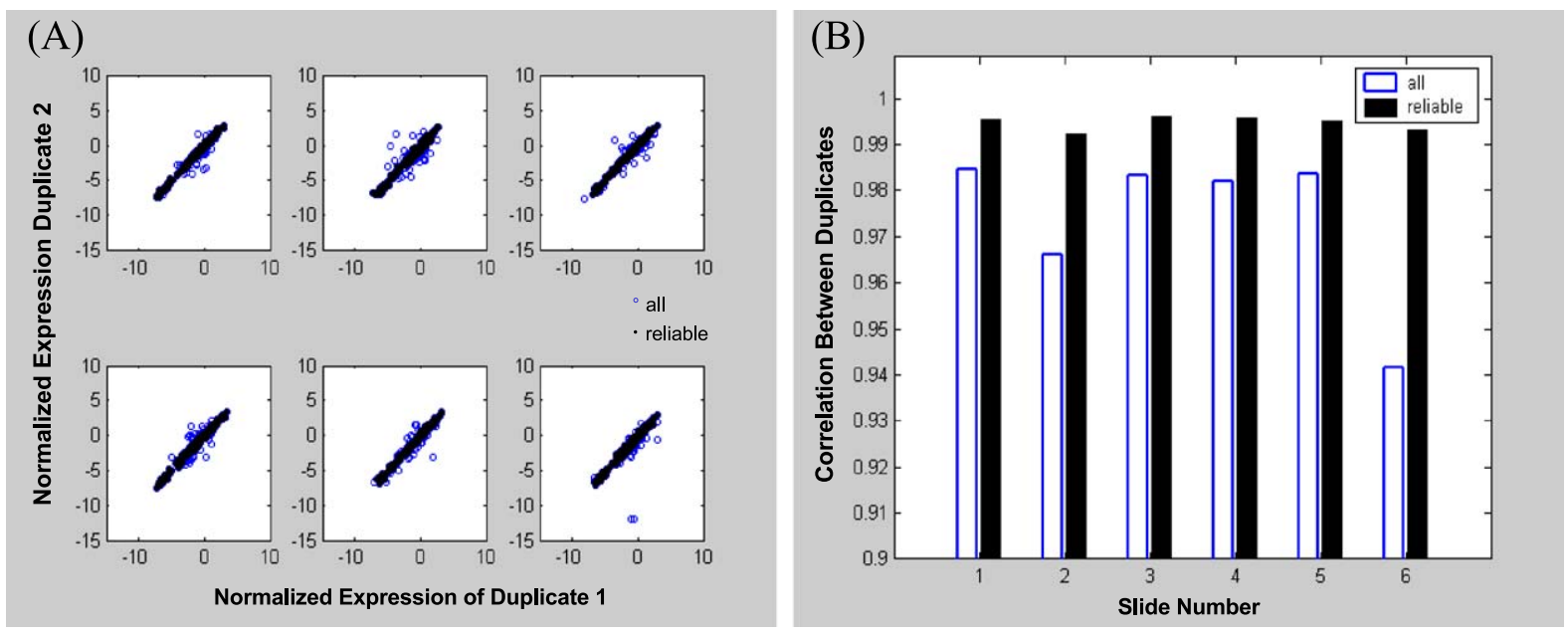

Fig. 2. Identification and filtering of outliers. Panel (A): for each slide used in the study ( $N=6$; slides $1-3$ for control and $4-6$ for nicotine-treated group), reliable and unreliable measurements (solid and open circles, respectively) were identified based on robust regression. Panel (B): use of this statistical method resulted in a consistent increase in the correlation coefficients between duplicate measurements across all slides (open and solid bars represent the degree of correlation between duplicates before and after filtering of outliers, respectively). Mean correlation coefficient was significantly increased from $0.974 \pm 0.017$ to $0.995 \pm 0.002$ ( $P=0.03$ based on Wilcoxon signed rank test). 


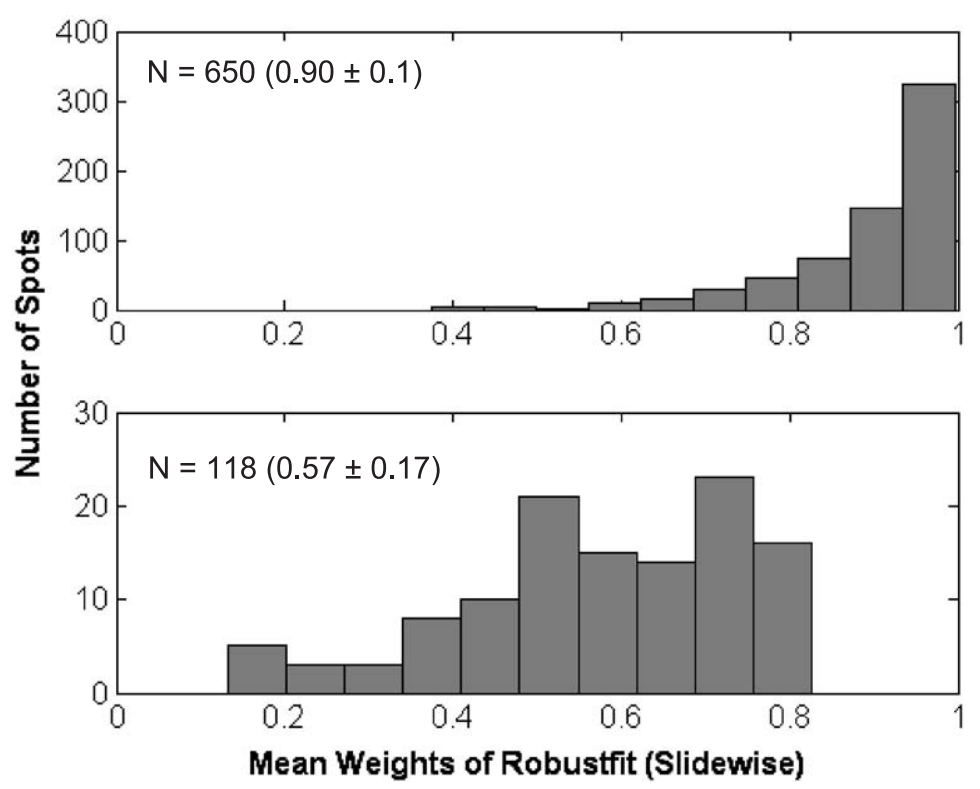

Fig. 3. Histogram of mean weights for reliable (top) and unreliable (bottom) spots for a total of six slides constituting the experiment reported in this study. Weights, which range from 0 to 1 with 0 being the least reliable, were generated by using robust regression between duplicate measurements on 768 spots/slide.

homeostasis was developed primarily based on the findings that nicotine is a potential modulator of calcium and PIdriven signaling pathways $[9,17,20]$. Fig. 1 represents an overview of the homeostatic pathway-focused microarray, in which PI biosynthetic signaling is placed at the core of crosstalking pathways (http://www.genome.ad.jp/kegg/ kegg2.html; www.biocarta.com).

It has been suggested that sequence verification of clones to be printed on a chip is necessary, since both public and commercial clone sets may contain a considerable amount of misidentified clones that might not be annotated correctly $[10,13]$. We sequenced all 704 clones from which 638 were confirmed and/or reannotated. The remaining 66 genes could not be confirmed because they did not match any sequence deposited in GenBank. Accordingly, our array analysis was based on 638 sequence-verified and fully annotated genes, which in turn could be classified into 10 major functional categories (Table 1).

\subsection{Replicate reliability and slide quality}

The hybridization intensity of a clone does not only depend on its mRNA expression level, but also could be influenced by experimental errors associated with PCR amplification, printing, hybridization, and washing procedures. Repetitive printing of the same clone allows for the estimation of such variability $[18,20,36]$. Statistical analyses indicated that duplicate measurements of our arrays obtained from the hybridization of the same RNA sample were highly correlated even before filtering of outliers (i.e., mean corre-

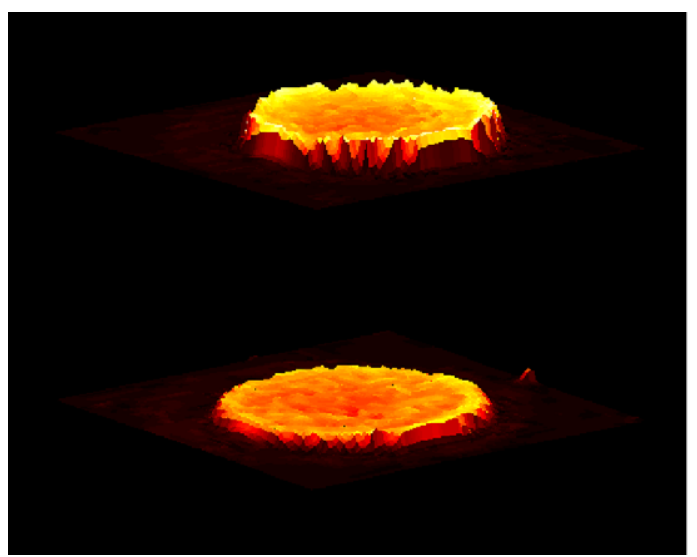

Rat beta nerve growth factor

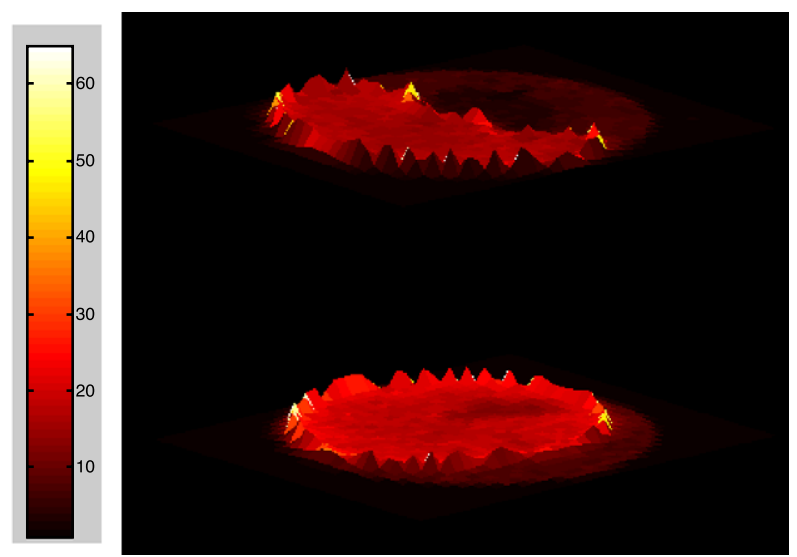

Proteasome 26S, non-ATPase subunit 7

Fig. 4. Examples of duplicated spots (Dup1 and Dup2) and their associated weights based on robust regression. A weight of zero indicates that the difference between duplicate measurements is large enough to consider that spot as an outlier. The differences between duplicate measurements are proportionally reflected in their fold differences with respect to mean intensity of the control samples. 
Table 2

A list of genes that are significantly modulated by nicotine after $48 \mathrm{~h}$ exposure in PC-12 cells $(P<0.005)$

\begin{tabular}{|c|c|c|c|c|}
\hline Symbol & Gene name & $\begin{array}{l}\text { Fold } \\
\text { change }\end{array}$ & Probability & Reliability \\
\hline \multicolumn{5}{|c|}{ Protein modification/degradation } \\
\hline Hsp105 & heat-shock protein, $105 \mathrm{kDa}$ & 1.32 & 0.00261 & 0.93 \\
\hline Hsp30 & heat-shock protein 030 & 1.34 & 0.00259 & 0.99 \\
\hline Psmb1 & $\begin{array}{l}\text { rat mRNA for proteasome } \\
\text { subunit RC5 }\end{array}$ & 1.20 & 0.00001 & 0.99 \\
\hline Psma2 & $\begin{array}{l}\text { proteasome (prosome, } \\
\text { macropain) subunit, alpha } \\
\text { type } 2\end{array}$ & 1.57 & 0.00106 & 0.98 \\
\hline Psma5 & $\begin{array}{l}\text { proteasome (prosome, } \\
\text { macropain) subunit, alpha } \\
\text { type } 5\end{array}$ & 1.38 & 0.00152 & 0.96 \\
\hline Ube $2 \mathrm{i}$ & $\begin{array}{l}\text { ubiquitin-conjugating enzyme } \\
\text { E2I }\end{array}$ & 1.17 & 0.00202 & 0.98 \\
\hline Smt3h2 & $\begin{array}{l}\text { Mus musculus SMT3 } \\
\text { (suppressor of mif two, 3) } \\
\text { homolog } 2\end{array}$ & 1.26 & 0.00003 & 0.98 \\
\hline Ube2a & $\begin{array}{l}\text { ubiquitin-conjugating enzyme } \\
\text { HR6A }\end{array}$ & 1.41 & 0.00391 & 0.95 \\
\hline Ube $3 b$ & $\begin{array}{l}\text { Mus musculus } \\
\text { ubiquitin-protein ligase } \\
\text { UBE3B }\end{array}$ & 0.78 & 0.00044 & 0.92 \\
\hline \multicolumn{5}{|c|}{ Protein synthesis } \\
\hline Rp19 & ribosomal protein L9 & 1.48 & 0.00103 & 0.97 \\
\hline Rpl27 & ribosomal protein L27 & 1.33 & 0.00002 & 0.96 \\
\hline Rps6 & ribosomal protein S6 & 1.49 & 0.00083 & 0.95 \\
\hline Rps4x & $\begin{array}{l}\text { ribosomal protein } \mathrm{S} 4 \text {, } \\
\mathrm{X} \text {-linked }\end{array}$ & 1.39 & 0.00142 & 0.93 \\
\hline Rpl35a & ribosomal protein $\mathrm{L} 35 \mathrm{a}$ & 1.37 & 0.00220 & 0.99 \\
\hline Rpl37a & ribosomal protein L37a & 1.35 & 0.00017 & 0.98 \\
\hline Rpl3 & ribosomal protein L3 & 1.22 & 0.00071 & 1.00 \\
\hline Rps24 & ribosomal protein S24 & 1.27 & 0.00036 & 0.97 \\
\hline Rps8 & ribosomal protein $\mathrm{S} 8$ & 1.23 & 0.00134 & 0.99 \\
\hline Rpl10 & ribosomal protein 10 & 1.34 & 0.00045 & 0.92 \\
\hline Rp141 & ribosomal protein L41 & 1.53 & 0.00014 & 0.89 \\
\hline \multicolumn{5}{|c|}{ Cellular signaling } \\
\hline Prkcz & protein kinase $\mathrm{C}$, zeta & 0.81 & 0.00027 & 0.95 \\
\hline Prkcb1 & protein kinase $\mathrm{C}$ beta & 0.85 & 0.00337 & 0.98 \\
\hline Npy & neuropeptide $\mathrm{Y}$ & 0.77 & 0.00014 & 0.94 \\
\hline Bdkrb2 & bradykinin receptor B2 & 0.87 & 0.00474 & 0.98 \\
\hline Frap1 & $\begin{array}{l}\text { FKBP-rapamycin-associated } \\
\text { protein }\end{array}$ & 0.82 & 0.00013 & 0.94 \\
\hline Adcy3 & $\begin{array}{l}\text { Rattus norvegicus type III } \\
\text { adenylyl cyclase }\end{array}$ & 0.83 & 0.00184 & 0.99 \\
\hline Fosl2 & fos-like antigen 2 & 0.81 & 0.00150 & 0.91 \\
\hline Ptprj & $\begin{array}{l}\text { protein tyrosine phosphatase, } \\
\text { receptor type, J }\end{array}$ & 0.84 & 0.00110 & 0.94 \\
\hline Cdk5 & cyclin-dependent kinase 5 & 0.86 & 0.00135 & 0.94 \\
\hline Cdc25a & $\begin{array}{l}\text { cell division cycle } 25 \\
\text { homolog A (S. cerevisiae) }\end{array}$ & 0.78 & 0.00005 & 0.96 \\
\hline Ilk & integrin-linked kinase & 1.22 & 0.00080 & 0.94 \\
\hline Abl1 & $\begin{array}{l}\text { Abelson murine leukemia } \\
\text { oncogene }\end{array}$ & 1.27 & 0.00067 & 0.96 \\
\hline Csnk2a2 & $\begin{array}{l}\text { casein kinase II, alpha } 2 \text {, } \\
\text { polypeptide }\end{array}$ & 1.25 & 0.00035 & 0.96 \\
\hline Nfkb1 & $\begin{array}{l}\text { nuclear factor of kappa light } \\
\text { chain gene enhancer in } \\
\text { B-cells } 1, \text { p105 }\end{array}$ & 1.41 & 0.00220 & 0.86 \\
\hline Celsr3 & $\begin{array}{l}\text { Rattus norvegicus mRNA for } \\
\text { MEGF2 }\end{array}$ & 1.12 & 0.00081 & 0.95 \\
\hline
\end{tabular}

Table 2 (continued)

\begin{tabular}{|c|c|c|c|c|}
\hline Symbol & Gene name & $\begin{array}{l}\text { Fold } \\
\text { change }\end{array}$ & Probability & Reliability \\
\hline \multicolumn{5}{|c|}{ Cellular signaling } \\
\hline Cald1 & caldesmon 1 & 1.15 & 0.00036 & 0.93 \\
\hline Stat2 & $\begin{array}{l}\text { signal transducer and } \\
\text { activator of transcription } 2\end{array}$ & 1.24 & 0.00151 & 0.92 \\
\hline Rpo2tc1 & $\begin{array}{l}\text { RNA polymerase II } \\
\text { transcriptional coactivator }\end{array}$ & 1.28 & 0.00250 & 0.97 \\
\hline \multicolumn{5}{|c|}{ Lipid metabolism/transport } \\
\hline Apoc3 & apolipoprotein C-III & 0.83 & 0.00327 & 0.88 \\
\hline Apoa4 & apolipoprotein A-IV & 0.84 & 0.00438 & 0.99 \\
\hline Fabp3 & $\begin{array}{l}\text { rat low-molecular-weight } \\
\text { fatty acid binding protein }\end{array}$ & 0.89 & 0.00418 & 0.98 \\
\hline Slc27a1 & $\begin{array}{l}\text { Rattus norvegicus fatty acid } \\
\text { transport protein }\end{array}$ & 0.81 & 0.00392 & 0.94 \\
\hline \multicolumn{5}{|c|}{ Neuronal transmission } \\
\hline S100b & $\begin{array}{l}\text { S100 calcium-binding } \\
\text { protein, beta (neural) }\end{array}$ & 0.82 & 0.00109 & 0.88 \\
\hline Nptx1 & $\begin{array}{l}\text { Rattus norvegicus neuronal } \\
\text { pentraxin precursor mRNA, } \\
\text { complete cds }\end{array}$ & 0.77 & 0.00003 & 0.93 \\
\hline $\operatorname{Dlg} 1$ & $\begin{array}{l}\text { Drosophila discs-large } \\
\text { tumor suppressor homologue } \\
\text { (synapse associated protein) }\end{array}$ & 0.80 & 0.00009 & 0.95 \\
\hline
\end{tabular}

Gene symbols and fold change observed upon $48 \mathrm{~h}$ of nicotine exposure and associated probability values (based on ANOVA) as well as mean duplicate reliability of the printed spots are also given.

lation coefficient across six slides was $0.974 \pm 0.017$ ). Application of robust regression has identified an average of $29 \pm 5$ [i.e., $3.75 \pm 0.6 \%$ (S.D.)] of the 768 duplicated spots as unreliable. Correlation between the duplicate measurements improved significantly upon removal of the outliers, as determined by the robust regression, such that the mean correlation coefficient increased to $0.995 \pm 0.002$ ( $P=0.03$, Wilcoxon signed rank test, Matlab ${ }^{\circledR}$; Fig. 2). Together, there were 650 reliable spots out of 768 (i.e., $85 \%$ ) with weights greater than 0 on all arrays used in the experiment. Accordingly, reliable measurements had a mean weight of $0.9 \pm 0.1$ (S.D.), whereas a mean weight of unreliable measurements was found to be $0.57 \pm 0.7$ based on six microarray hybridizations (Fig. 3). Indeed, spot quality between duplicates varied with respect to the magnitude of hybridization intensity and spot morphology (see examples given in Fig. 4). The weight associated with each spot pair provided a quantitative assessment of the spot quality, which eventually was reflected in the fold change in gene expression with respect to the average intensity of that clone obtained from controls (e.g., \% of gene expression relative to control; Fig. 4). We also assessed the level of correlation when independent RNA samples were used by calculating a correlation coefficient between every possible pair of slides $\left(N_{\text {slides }}=6\right)$. We found that the average between-slide correlation coefficients before and after outlier filtering were $0.9372 \pm 0.0228\left(N_{\text {spots }}=768 \times 2\right)$ and $0.9759 \pm 0.0046\left(N_{\text {spots }}=650 \times 2\right)$, respectively. These findings suggested that observed differences between individual 


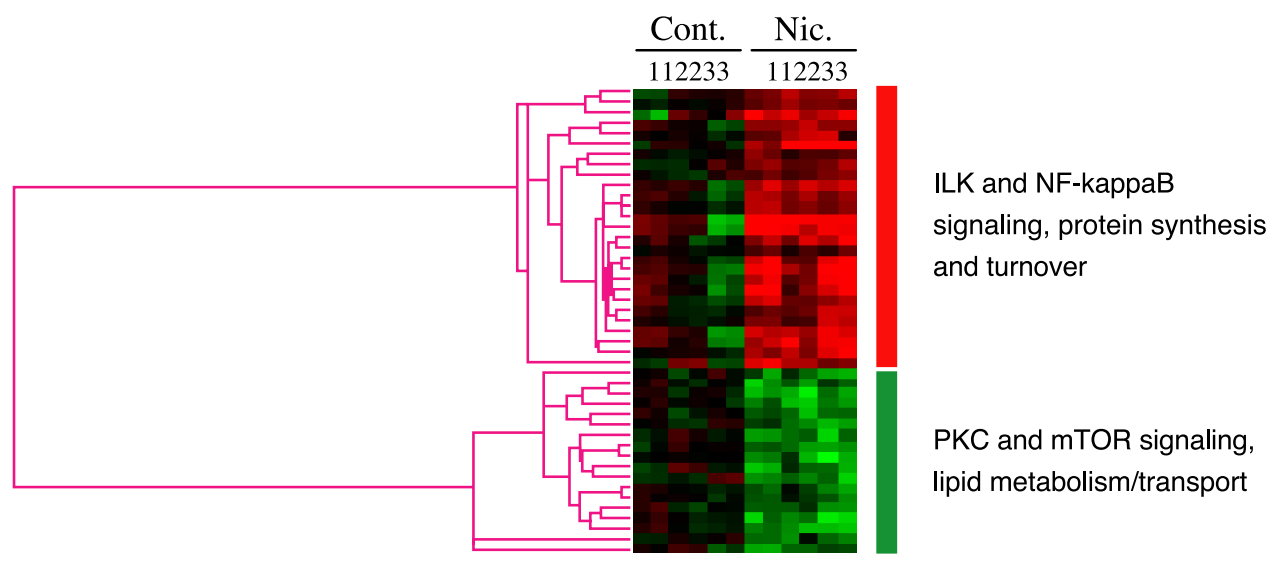

Fig. 5. Hierarchical clustering of 45 differentially expressed genes at a significance level of $P \leq 0.005$ with a normalized expression level $\geq-2.5$ and mean duplicate reliability $\geq 0.8$ between control (Cont.) and nicotine (Nic.)-treated PC-12 cells. Each group has three independent replicates that were measured in duplicate per gene/slide. For each gene, red and green colors were used to indicate upregulation and downregulation, respectively, of mRNA expression relative to the mean gene expression of control samples. Abbreviations: ILK: integrin-linked kinase; NF-kappaB: nuclear factor kappa B; PKC: protein kinase C; mTOR: mammalian target of rapamycin.

sample expression profiles were due to changes in a small number of genes/ESTs. Furthermore, our statistical analyses demonstrated a very high degree of repeatability of slides that were processed in this laboratory.

\subsection{Gene expression profiling of nicotine-treated PC-12 cells}

A total of 45 genes were found to be significantly upregulated or downregulated in PC-12 cells upon exposure to nicotine ( $\mathrm{P} \leq 0.005$; Table 2). Interestingly, genes that were transcriptionally upregulated by nicotine included those that have been shown as positive effectors of AKT/ PKB and NF- $\mathrm{BB}$ signaling, as well as components of protein synthesis and turnover; ribosomal subunits, ubiquitin/proteasome degradation pathway, and heat-shock proteins (Fig. 5; see Table 2 for a complete listing). On the other hand, genes whose mRNA expression was downregulated by nicotine were those involved in lipid metabolism/transport and those that may exert negative feedback on the AKT/

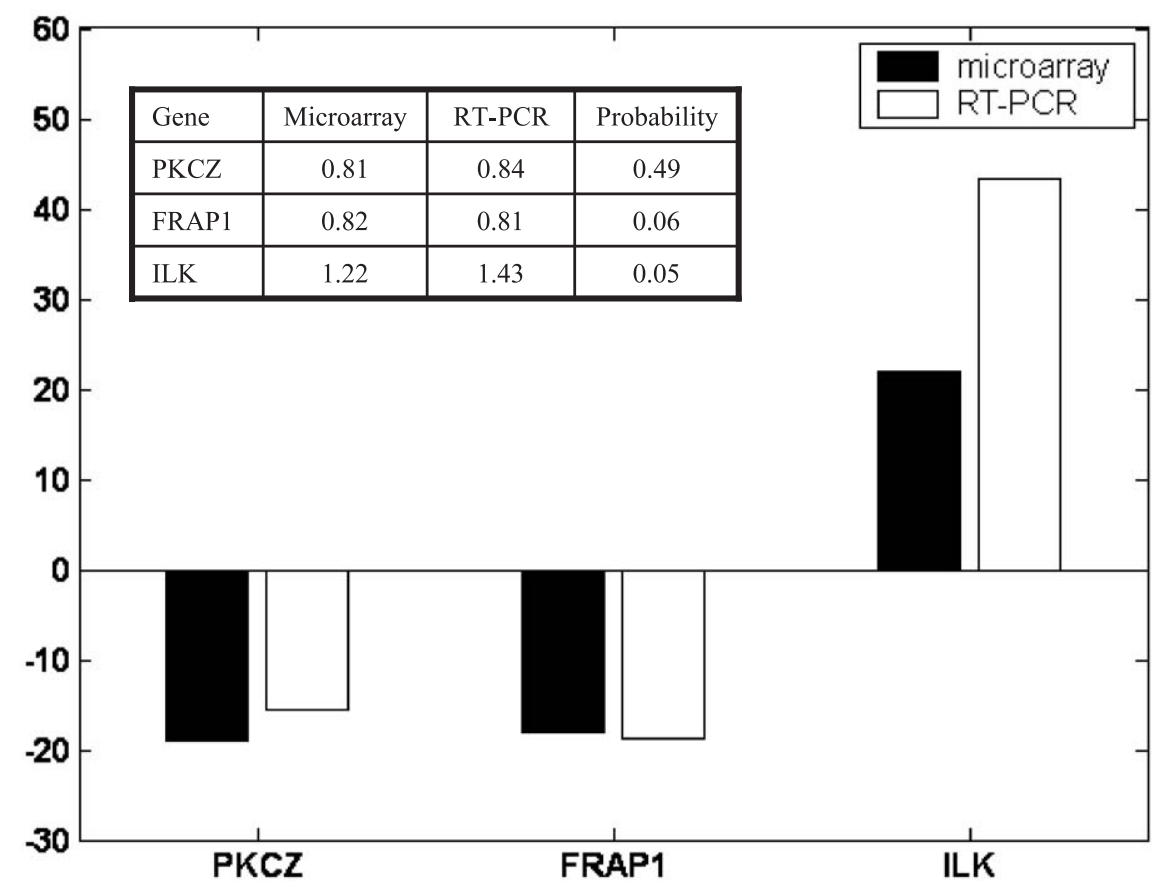

Fig. 6. Comparative plot of data from microarray and real-time RT-PCR verification for three representative genes. Y-axis represents the average percent change of expression in nicotine-treated PC-12 cells compared with the average expression in the control PC-12 cells for that particular gene. The comparative fold differences for microarray and real-time RT-PCR (and associated probability values) are given in the Insert. Abbreviation: X-axis: protein kinase C zeta (PKCZ); FK506 binding protein 12-rapamycin associated protein 1 (FRAP1), integrin-linked kinase (ILK). 
PKB signaling, such as PKC isoforms $\beta$ and $\zeta$, and nutrientsensitive FRAP1/mTOR (Table 2). Based on the results of microarray data, we have performed quantitative real-time RT-PCR on three representative genes that are important regulators of AKT/PKB signaling, namely, PKC $\zeta$, FRAP1/ mTOR, and ILK for further confirmation of the microarray experiments. Our findings indicated that microarray and RTPCR data exhibited a significant positive correlation $(R=0.9979, P=0.041)$ with respect to PKC $\zeta$, FRAP1, and ILK gene expression (Fig. 6).

\section{Discussion}

In this study, we report the development of a pathwayfocused microarray and its application to investigate the effect of nicotine on mRNA transcription in PC-12 cells. We show that this homeostatic pathway-focused microarray produced highly reliable data with respect to the variability observed between spots printed in duplicate. Furthermore, transcriptional profiling of undifferentiated PC-12 cells upon $48 \mathrm{~h}$ of nicotine $(1 \mathrm{mM})$ exposure using the homeostatic pathway-focused cDNA microarray has led to a better understanding of the mechanisms underlying the global response in terms of the AKT/PKB signaling, metabolic, and stress response upon exposures to cholinergic stimuli.

Previous studies have indicated that use of replicated spotting significantly increases the reliability of the gene expression measurement for the particular spot under investigation and produces a statistical estimate for the withinspot variability in general $[2,17,18,20]$. In this study, we presented a statistical approach making use of robust regression for identification of unreliably measured spots. Accordingly, a weight was calculated for each spot of a slide, and several informative variables such as total number of flagged spots per slide, as well as the average experimental reliability, were estimated. Our results also indicated that this quality control step significantly increased the average correlation coefficients between duplicated spots within a slide while reducing the variability among slides with respect to duplicate correlation. Moreover, the weight associated with each paired spot varying between 0 and 1 accurately reflected the degree of difference between duplicate measurements and thus may represent a useful indicator in identifying significant and/or nonsignificant fold differences that may be due to error (i.e., reduced rate of false positives and negatives, respectively).

Based on the transcriptional profiling of PC-12 cells, we showed that the homeostatic pathway-focused microarray is able to reflect an intriguing snapshot of the global changes occurring in response to a highly modulatory cholinergic stimulus, i.e., nicotine exposure. Nicotine, which is a potent agonist of nicotinic acetylcholine receptors and an efficient modulator of intracellular calcium concentration, plays a major role in the control of catecholamine synthesis and release from PC-12 as well as adrenal medullary chromaffin cells $[9,14]$. It is evident that elevation of $\left[\mathrm{Ca}^{2+}\right]_{\mathrm{i}}$ is essential for the initiation and maintenance of neurotransmitter synthesis and release. Even though calcium homeostasis is integral for the actions of agonist-activated nicotinic acetycholine receptors on cellular signaling and neurotransmitter synthesis/release, studies deciphering genetic networks underlying such a modulatory behavior have only recently gained momentum $[17,20]$. A homeostatic pathway-focused microarray consisting of calcium homeostasis and phosphatidylinositol signaling pathway-related genes allowed us to gain insights into nicotine's actions on AKT/PKB signaling and its downstream targets FRAP1/mTOR and NF- $\mathrm{kB}$, as well as on regulation of protein synthesis and degradation in a secretory system such as PC-12 cells responsive to nicotine.

According to our microarray and RT-PCR results, it appears that nicotine affects AKT/PKB signaling at the transcriptional level via downregulation of $\mathrm{PKC}$ isoforms $\zeta$ and $\beta$ and upregulation of integrin-linked kinase, ILK (Table 2; Figs. 6 and 7). Interestingly, a recent study has shown that AKT is constitutively activated by nicotine in non-immortalized human airway epithelial cells as indicated by increased phosphorylation of its downstream substrates [40]. Constitutive activation of AKT, a downstream target of phosphoinositide 3-kinase (PI3K), has been implicated in the pathogenesis of various cancers [25], making it a promising therapeutic target. Recently, PKC and ILK have emerged as potent regulatory components of AKT activity [39]. In particular, ceramide activation of PKC $\zeta$ was shown to inhibit AKT activity [3] via a possible physical interaction between PKC $\zeta$ and AKT [8]. In regards to the nicotinic acetylcholine receptors, ceramide also was shown to inhibit voltage-gated calcium activity, thus leading to a reduction in the nicotine-induced $\mathrm{Ca}^{+}$ signaling and catecholamine secretion in adrenal chromaffin cells [22]. In our study, we found that $\mathrm{PKC} \zeta$ expression along with that of PKC $\beta$ was significantly reduced in PC12 cells exposed to nicotine for $48 \mathrm{~h}$, suggesting that nicotine may play a role in altering the negative feedback on AKT activity via modulations in PKC $\zeta$ (Table 2 and Fig. 6 and 7). On the other hand, AKT/PKB is activated through phosphorylation at serine 473 by ILK $[27,39]$, whose mRNA expression was shown to be upregulated by nicotine in this study (Table 2 and Figs. 6 and 7). In accordance with the findings reported by West et al. [40], our results suggest that PKC isoforms and ILK represent potentially important candidates modulating the constitutive activation of AKT by nicotine (Fig. 7). Furthermore, activation of AKT by nicotine provides a possible connection with the involvement of NF-KB in response to nicotine. A recent study has shown that non-neuronal nicotinic acetylcholine receptor activation resulted in increased AKT/NF- $\kappa \mathrm{B}$ activity in different models of angiogenesis [11]. Our results might further shed light on the observed relationship between nicotine and NF-kB (Fig. 7). First, nicotine increased mRNA expression of NF- $\kappa \mathrm{B}$ p105 


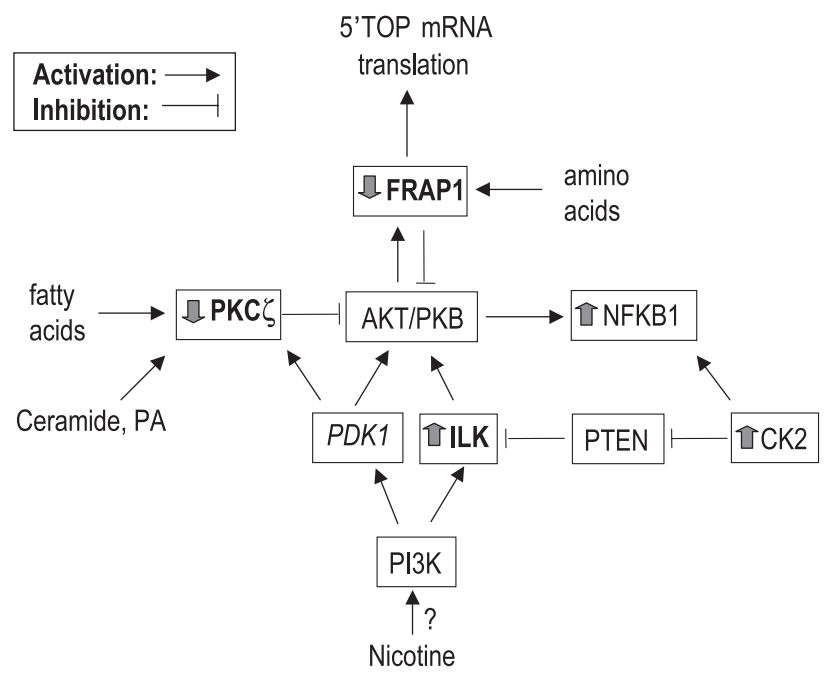

Fig. 7. Proposed effects of nicotine on AKT/PKB signaling pathway in PC12 cells based on homeostatic pathway-focused microarray expression profiling. PI3K induces PDK-1 and ILK, which differentially phosphorylate AKT/PKB leading to its full activation. On the other hand, suppression of ILK by PTEN represses AKT signaling. PKC $\zeta$ inhibits AKT activity by physically interacting with it; thus, its inhibition positively feedbacks the activity of AKT signaling downstream targets, i.e., NF- $\mathrm{B}$ and mammalian target of rapamycin, mTOR. The kinase involved in inhibition of PTEN is CK2- $\alpha$, which in turn is involved in the activation of NFKB1, an important component of cellular inflammatory response. mTOR regulates the translation of a set of mRNAs known as 5'TOP mRNA(e.g., ribosomal subunits). Finally, nutrients, such as amino acids and fatty acids, also may regulate the degree to which AKT signaling could be activated, suggesting that nicotine is also capable of modulating the cellular behavior indirectly through its effects on metabolism. Genes that are transcriptionally downregulated or upregulated are indicated by filled arrows. Genes shown in bold indicate that nicotine-induced change in expression is confirmed using RT-PCR, whereas the effects of nicotine on genes shown in italics are not determined since those genes are not present in the microarray. Abbreviations: mTOR: mammalian target of rapamycin; PKC $\zeta$ : protein kinase zeta; AKT/PKB: v-akt murine thymoma viral oncogene homolog; NFKB1: nuclear factor kappa B (p105); PDK1: 3-phosphoinositidedependent protein kinase-1; ILK: integrin-linked kinase; PTEN: phosphate and tensin homolog; CK2: casein kinase 2 alpha 2; PI3K: phosphoinositide3-kinase; PA: phosphatidic acid.

(NFKB1) together with casein kinase II $\alpha$ (CK2), which was shown to constitutively activate NF- $\mathrm{BB}$ in cancer cells [28]. Second, CK2 inhibits phosphatase and tensin homo$\log$, PTEN, an important negative regulator of PI3K/ILK/ AKT signaling [24,26]. Accordingly, CK2 emerges as a candidate target of cholinergic stimulus for further study.

We also showed that nicotine led to transcriptional upregulation of a set of genes involved in protein synthesis and protein modification/degradation in $\mathrm{PC}-12$ cells upon $48 \mathrm{~h}$ of exposure (Table 2). The consistent increase in the ribosomal subunit mRNA expression by nicotine suggests that activity of the protein synthetic machinery might have been modulated. Ribosomal subunit mRNAs belong to a unique class of mRNAs that are translationally regulated by mitogenic signals through their 5 ' terminal oligopyrimidine tract, i.e., 5'TOP mRNAs [23,31]. Previous studies indicated that ribosomal subunits were responsive to changes in the nutrient and amino acid availability as well as to events such as neuronal differentiation upon nerve growth factor treatment $[1,33]$. Furthermore, the nicotine-induced modulations in AKT signaling (as discussed above) may have implications in the nutrient-sensitive FRAP1/mTOR signaling pathway involved in the regulation of ribosomal protein synthesis [34]. AKT is an upstream kinase for the activation of FRAP1/mTOR, which, in turn, may negatively feedback AKT activity depending on the nutritional status of the cell [35]. Accordingly, the observed increase in the ribosomal mRNA pool and decrease in FRAP1 mRNA expression upon chronic nicotine exposure might indicate a state of translational repression (Fig. 7). However, further studies are needed to test whether nicotine results in a change in the pattern of allocation of ribosomal subunit mRNAs between subpolysomal and polysomal components, the latter being actively translated. Our findings also indicated that several genes involved in protein modification and degradation were significantly upregulated by nicotine (Table 2). These genes include proteasomal subunits of protein degradation, SUMO and ubiquitin pathway-related genes involved in postreplicative DNA repair (i.e., Smt3h2/Ube2i and Ube2a), and heat shock genes that are known to be upregulated in cellular stress conditions [12]. These results suggest that nicotine might have induced a stressful condition in the cells, eventually resulting in DNA damage and hence, increased DNA repair.

The primary incentive for the design of a homeostatic pathway-focused array was to profile a collection of genes belonging to signaling pathways that are either known or suspected to be involved in $\left[\mathrm{Ca}^{2+}\right]_{\mathrm{i}}$ homeostasis in response to cholinergic stimuli. However, since $\left[\mathrm{Ca}^{2+}\right]_{i}$ homeostasis and its modulation are important in processes as diverse as neurotransmitter release and tissue pathogenesis including tumor formation, the homeostatic pathway-focused microarray is expected to be applicable to a wide range of studies conducted in the biological field. Accordingly, the comprehensive nature of the homeostatic pathway-focused microarray provides an excellent opportunity for performing comparative studies on drugs of abuse, as well as on signaling pathways sensitive to internal and external environmental stimuli, such as starvation, hypoxia, growth factors, and neurotransmitters.

\section{Acknowledgments}

This project was in part supported by National Institute of Health grants R01 DA-13783 and DA-12844 to MDL.

\section{References}

[1] J.M. Angelastro, B. Torocsik, L.A. Greene, Nerve growth factor selectively regulates expression of transcripts encoding ribosomal proteins, BMC Neurosci. 3 (2002) 3. 
[2] M.A. Black, R.W. Doerge, Calculation of the minimum number of replicate spots required for detection of significant gene expression fold change in microarray experiments, Bioinformatics 18 (2002) $1609-1616$.

[3] N.A. Bourbon, L. Sandirasegarane, M. Kester, Ceramide-induced inhibition of Akt is mediated through protein kinase Czeta: implications for growth arrest, J. Biol. Chem. 277 (2002) 3286-3292.

[4] S.A. Bustin, Absolute quantification of mRNA using real-time reverse transcription polymerase chain reaction assays, J. Mol. Endocrinol. 25 (2000) 169-193.

[5] C.H. Chung, P.S. Bernard, C.M. Perou, Molecular portraits and the family tree of cancer, Nat. Genet. 32 (2002) 533-540 (Suppl.).

[6] G.A. Churchill, Fundamentals of experimental design for cDNA microarrays, Nat. Genet. 32 (Suppl. 2) (2002) 490-495.

[7] V. Colangelo, J. Schurr, M.J. Ball, R.P. Pelaez, N.G. Bazan, W.J. Lukiw, Gene expression profiling of 12633 genes in Alzheimer hippocampal CA1: transcription and neurotrophic factor down-regulation and up-regulation of apoptotic and pro-inflammatory signaling, J. Neurosci. Res. 70 (2002) 462-473.

[8] R.P. Doornbos, M. Theelen, P.C. van der Hoeven, W.J. van Blitterswijk, A.J. Verkleij, P.M. van Bergen en Henegouwen, Protein kinase Czeta is a negative regulator of protein kinase B activity, J. Biol. Chem. 274 (1999) 8589-8596.

[9] V.D. Gueorguiev, R.J. Zeman, B. Hiremagalur, A. Menezes, E.L. Sabban, Differing temporal roles of $\mathrm{Ca}^{2+}$ and cAMP in nicotineelicited elevation of tyrosine hydroxylase mRNA, Am. J. Physiol. 276 (1999) C54-C65.

[10] R.G. Halgren, M.R. Fielden, C.J. Fong, T.R. Zacharewski, Assessment of clone identity and sequence fidelity for 1189 IMAGE cDNA clones, Nucleic Acids Res. 29 (2001) 582-588.

[11] C. Heeschen, M. Weis, A. Aicher, S. Dimmeler, J.P. Cooke, A novel angiogenic pathway mediated by non-neuronal nicotinic acetylcholine receptors, J. Clin. Invest. 110 (2002) 527-536.

[12] C. Hoege, B. Pfander, G.L. Moldovan, G. Pyrowolakis, S. Jentsch, RAD6-dependent DNA repair is linked to modification of PCNA by ubiquitin and SUMO, Nature 419 (2002) 135-141.

[13] A.J. Holloway, R.K. van Laar, R.W. Tothill, D.D. Bowtell, Options available - from start to finish-for obtaining data from DNA microarrays II, Nat. Genet. 32 (2002) 481-489 (Suppl.).

[14] M.S. Jorgensen, P.G. Wagner, W.A. Arden, B.A. Jackson, Modulation of stimulus-secretion coupling in porcine adrenal chromaffin cells by receptor-mediated increases in protein kinase C activity, J. Neurosci. Res. 59 (2000) 760-766.

[15] M.K. Kerr, G.A. Churchill, Statistical design and the analysis of gene expression microarray data, Genet. Res. 77 (2001) 123-128.

[16] T. Kihara, S. Shimohama, H. Sawada, K. Honda, T. Nakamizo, H. Shibasaki, T. Kume, A. Akaike, Alpha 7 nicotinic receptor transduces signals to phosphatidylinositol 3-kinase to block A betaamyloid-induced neurotoxicity, J. Biol. Chem. 276 (2001) $13541-13546$

[17] O. Konu, J.K. Kane, T. Barrett, M.P. Vawter, R. Chang, J.Z. Ma, D.M. Donovan, B. Sharp, K.G. Becker, M.D. Li, Region-specific transcriptional response to chronic nicotine in rat brain, Brain Res. 909 (2001) $194-203$

[18] M.L. Lee, F.C. Kuo, G.A. Whitmore, J. Sklar, Importance of replication in microarray gene expression studies: statistical methods and evidence from repetitive cDNA hybridizations, Proc. Natl. Acad. Sci. U. S. A. 97 (2000) 9834-9839.

[19] M.D. Li, G.J. MacDonald, J.J. Ford, Breed differences in expression of inhibin/activin subunits in porcine anterior pituitary glands, Endocrinology 138 (1997) 712-718.

[20] M.D. Li, O. Konu, J.K. Kane, K.G. Becker, Microarray technology and its application on nicotine research, Mol. Neurobiol. 25 (2002) $265-285$.

[21] M.D. Li, J.K. Kane, O. Konu, Nicotine, body weight and potential implications in the treatment of obesity, Curr. Top. Med. Chem. 3 (2003) 899-919.
[22] J. Liu, M.S. Jorgensen, J.M. Adams, W.B. Titlow, M. Nikolova-Karakashian, B.A. Jackson, Ceramide modulates nicotinic receptor-dependent $\mathrm{Ca}^{2+}$ signaling in rat chromaffin cells, J. Neurosci. Res. 66 (2001) 559-564

[23] O. Meyuhas, Synthesis of the translational apparatus is regulated at the translational level, Eur. J. Biochem. 267 (2000) 6321-6330.

[24] S.J. Miller, D.Y. Lou, D.C. Seldin, W.S. Lane, B.G. Neel, Direct identification of PTEN phosphorylation sites, FEBS Lett. 528 (2002) $145-153$.

[25] L.M. Neri, P. Borgatti, S. Capitani, A.M. Martelli, The nuclear phosphoinositide 3-kinase/AKT pathway: a new second messenger system, Biochim. Biophys. Acta 1584 (2002) 73-80.

[26] S. Persad, S. Attwell, V. Gray, M. Delcommenne, A. Troussard, J. Sanghera, S. Dedhar, Inhibition of integrin-linked kinase (ILK) suppresses activation of protein kinase B/Akt and induces cell cycle arrest and apoptosis of PTEN-mutant prostate cancer cells, Proc. Natl. Acad. Sci. U. S. A. 97 (2000) 3207-3212.

[27] S. Persad, S. Attwell, V. Gray, N. Mawji, J.T. Deng, D. Leung, J. Yan, J. Sanghera, M.P. Walsh, S. Dedhar, Regulation of protein kinase B/ Akt-serine 473 phosphorylation by integrin-linked kinase: critical roles for kinase activity and amino acids arginine 211 and serine 343, J. Biol. Chem. 276 (2001) 27462-27469.

[28] R. Romieu-Mourez, E. Landesman-Bollag, D.C. Seldin, G.E. Sonenshein, Protein kinase CK2 promotes aberrant activation of nuclear factor-kappaB, transformed phenotype, and survival of breast cancer cells, Cancer Res. 62 (2002) 6770-6778.

[29] M. Saito, J. Smiley, R. Toth, C. Vadas, Microarray analysis of gene expression in rat hippocampus after chronic ethanol treatment, Neurochem. Res. 27 (2002) 1221-1229.

[30] G.P. Sawiris, C.A. Sherman-Baust, K.G. Becker, C. Cheadle, D. Teichberg, P.J. Morin, Development of a highly specialized cDNA array for the study and diagnosis of epithelial ovarian cancer, Cancer Res. 62 (2002) 2923-2928.

[31] M. Stolovich, H. Tang, E. Hornstein, G. Levy, R. Cohen, S.S. Bae, M.J. Birnbaum, O. Meyuhas, Transduction of growth or mitogenic signals into translational activation of TOP mRNAs is fully reliant on the phosphatidylinositol 3-kinase-mediated pathway but requires neither S6K1 nor rpS6 phosphorylation, Mol. Cell. Biol. 22 (2002) $8101-8113$.

[32] T.S. Tanaka, S.A. Jaradat, M.K. Lim, G.J. Kargul, X. Wang, M.J. Grahovac, S. Pantano, Y. Sano, Y. Piao, R. Nagaraja, H. Doi, W.H. Wood III, K.G. Becker, M.S. Ko, Genome-wide expression profiling of mid-gestation placenta and embryo using a 15,000 mouse developmental cDNA microarray, Proc. Natl. Acad. Sci. U. S. A. 97 (2000) 9127-9132.

[33] K. Tang, H. Wu, S.K. Mahata, M. Mahata, B.M. Gill, R.J. Parmer, D.T. O'Connor, Stimulus coupling to transcription versus secretion in pheochromocytoma cells. Convergent and divergent signal transduction pathways and the crucial roles for route of cytosolic calcium entry and protein kinase C, J. Clin. Invest. 100 (1997) $1180-1192$.

[34] H. Tang, E. Hornstein, M. Stolovich, G. Levy, M. Livingstone, D. Templeton, J. Avruch, O. Meyuhas, Amino acid-induced translation of TOP mRNAs is fully dependent on phosphatidylinositol 3-kinasemediated signaling, is partially inhibited by rapamycin, and is independent of S6K1 and rpS6 phosphorylation, Mol. Cell. Biol. 21 (2001) 8671-8683.

[35] F. Tremblay, A. Marette, Amino acid and insulin signaling via the $\mathrm{mTOR} / \mathrm{p} 70$ S6 kinase pathway. A negative feedback mechanism leading to insulin resistance in skeletal muscle cells, J. Biol. Chem. 276 (2001) 38052-38060.

[36] G.C. Tseng, M.K. Oh, L. Rohlin, J.C. Liao, W.H. Wong, Issues in cDNA microarray analysis: quality filtering, channel normalization, models of variations and assessment of gene effects, Nucleic Acids Res. 29 (2001) 2549-2557.

[37] R.N. Van Gelder, M.E. von Zastrow, A. Yool, W.C. Dement, J.D. Barchas, J.H. Eberwine, Amplified RNA synthesized from limited 
quantities of heterogeneous cDNA, Proc. Natl. Acad. Sci. U. S. A. 87 (1990) $1663-1667$.

[38] K. Walder, D. Segal, S. Chehab, G. Augert, D. Cameron-Smith, M. Hargreaves, G.R. Collier, A custom-built insulin resistance gene chip, Ann N.Y. Acad. Sci. 967 (2002) 274-282.

[39] H.C. Wen, W.C. Huang, A. Ali, J.R. Woodgett, W.W. Lin, Negative regulation of phosphatidylinositol 3-kinase and Akt signalling pathway by PKC, Cell. Signal. 15 (2003) 37-45.

[40] K.A. West, J. Brognard, A.S. Clark, I.R. Linnoila, X. Yang, S.M. Swain, C. Harris, S. Belinsky, P.A. Dennis, Rapid Akt activation by nicotine and a tobacco carcinogen modulates the phenotype of normal human airway epithelial cells, J. Clin. Invest. 111 (2003) $81-90$.

[41] J. Winer, C.K. Jung, I. Shackel, P.M. Williams, Development and validation of real-time quantitative reverse transcriptase-polymerase chain reaction for monitoring gene expression in cardiac myocytes in vitro, Anal. Biochem. 270 (1999) 41-49.

[42] E. Wurmbach, T. Yuen, B.J. Ebersole, S.C. Sealfon, Gonadotropinreleasing hormone receptor-coupled gene network organization, J. Biol. Chem. 276 (2001) 47195-47201.

[43] Y. Zick, Insulin resistance: a phosphorylation-based uncoupling of insulin signaling, Trends Cell Biol. 11 (2001) 437-441. 